\title{
Indigenous Cosmopolitanisms of Music in Sámi Theatre
}

In Sápmi, the historical lands of the Indigenous Sámi people, theatre flourishes with music as a central component. Staged music theatre thrives across the Sámi traditional areas in contemporary northern Norway, Sweden, Finland, and Russia. Sámi theatre companies emerged first in Sweden in 1971 (Dálvadis Theatre), and a decade later in Finland (Rávgoš Theatre, est. 1981) and Norway (Beaivváš Sámi Našunálateáhter, est. 1981), with additional developments later (Norway, Åarjelhsaemien Teatere, est. 1986; Sweden, Giron sámi teáhter, est. 1992; see Lehtola 2013). Russian productions have tended to feature Sámi ritual and folklore in public events and festivals. ${ }^{1}$ These contrast the Nordic productions often staged nowadays by professional and commercial theatre companies, my focus here.

The musical theatre productions - in genres familiar today including stage plays, dance theatre and opera-emerged in the Nordic countries from Sámi, for Sámi, in the 1970s and '80s, and in ways that responded to Sámi social and political contexts. In the words of Harriet Nordlund, the founder Dálvadis Theatre, Sámi theatre has always taken up "the job of the theatre to get people to look at their own situation and react to it" (Nordlund cited in Lehtola 2013: 439). The expression has responded to feelings and needs of theatre practitioners and audiences. In the 1970s and '80s, these needs were political. For instance, in Min Duoddarat (Our Fells), a rock opera produced by Beaivváš teáhter in 1981, young Sámi musicians including

\footnotetext{
1 Sámi theatre performances in the Russian Federation have happened at events in Murmansk Oblast (specifically Lovozero, Loparskaya and Molochny) on the Kola Peninsula. The events include festivals, Sámi competitions, Sámi summer games and events on Sámi National Day. One prominent Sámi theatre group is Narodnyj Teatr Saamskih Traditsij or the Folk Theatre of Sámi Traditions, which for example has produced Dancing Sámi (a.k.a. Ellmannt in Sámi and Tantsuyuschie saamy in Russian). The group - which consists of 16 people: five women, five girls, two men and four boys-describes itself in Russian as presenting the Legend of Sámi life in ancient times as well as rituals, theatre songs and old Sámi dances.
} 
Mari Boine presented a view on the Áltá Dam conflict—a dispute involving Sámi and the settler Norwegian government, over the flooding of Sámi reindeer pastures. Starting in the 1990s and through subsequent decades, needs broadened to include self-reflections and refreshing creations of "what is Sáminess" (Lehtola \& Magga 2011). Sámi culture scholar Veli-Pekka Lehtola insightfully observes Sámi theatre as making use of the "capacity of people to directly experience their own identity and fortify it [which makes] theatre a political art form" and "all drama [being] naturally political, because it either reinforces or weakens the code of behavior of a community" (Lehtola 2013: 442). In addition, many Sámi theatre productions in the Nordic countries have involved intercultural collaborations and international tours and, thus, address local, national, and international audiences from diverse backgrounds.

Studies on music in Sámi theatre thus far have explored how Sámi and non-Sámi take different meanings from a performance (Diamond 2011), and how the productions act as forums for sustaining the historical Sámi vocal expression joik, alternatively spelled as yoik (Harrison 2019). Even though a good part of the social and political work that Sámi theatre does reflects and creates what is Sámi, no publication has yet focused on the Sáminess of music in Sámi theatre. I do so with musically and culturally hybrid aspects of the music theatre performances in central focus.

Based on an ethnographic study consisting of participant observations, fieldnotes of performances, and interviews, this article asks: Which kinds of Sáminess are expressed and engaged with music in Sámi theatre? I argue that, in one view, musical sounds, and aspects and moments of Sámi theatre where music interacts with other theatre values such as speech, movement and costumes, present cosmopolitan versions of Sáminess. I focus most on productions from Norwegian Sápmi.

\section{Music in Sámi theatre}

In Norwegian, Swedish, and Finnish Sápmi, music theatre uses a variety of musical materials, including and beyond joik. This evidences how Sámi engage and make musical culture today. To echo Harald Gaski's question about writings on Sámi music: "Why in the world must almost all Sami music be associated with yoik when only a fraction of it has anything to do with traditional yoik?" (Gaski 2008: 359). While many of the theatre artists relate their creative processes with historical joik-in most cases not actually performing it, but as a sonic or conceptual inspiration-the resultant expressions, such as fusion musics and dance, reflect the everyday lived reality of Sámi artists in a globalized/globalizing world. After anthropologist Maximillian C. Forte, "the indigene and the cosmopolite [...] are one and the same" (Forte 2010: 14). 
At the same time, the performances interweave the "traditional" and the "modern" in both function and aesthetic (Levine and Robinson 2019; Robinson 2019). Sámi artists sometimes observe that the idea of combining music, theatre, and dance is relatively new to Sámi. Sámi did not have dance historically (Jürgensen i2014). In Sámi language, there is no word for theatre, music or dance. In the North Sámi language (spoken in northern Norway, Sweden and Finland), for example, the words for music (musihkka), dance (dánsut) and theatre (teahtár) have been adapted from other, non-Sámi languages (Gaski i2016). Indicating older words-likely from pre-colonial times about what would have been performed then - are the verb to joik (juoigat) as well as terms for song (lávlla), to sing (lávlut), drum (rumbu), to play an instrument (čuojahit) related to "musical instrument" (čuojanas), to tell or say (muitalit) and the related "tale" (muitalus) (see sanakirja.fi 2021). One implication is that theatre, music, and dance are concepts resulting from transnational and intercultural exchange and thus, cosmopolitan.

Many Sámi people understand both theatre and joik-inspired musical expressions as extending their traditions of storytelling - muitalandáidu in North Sámi. The Sámi artists I interviewed view music and other theatre values as acts of storying. The purpose of joiking is to convey the essence of the person, place, thing, or experience joiked (Diamond 2007; Moisala 2011), and in this way, to story through vocalization. Sámi music is also a highly politicized art form, engaged, like theatre, with indigeneity or Indigenous ethnic identity work (Hilder 2012; Jones-Bamman 1993; Jones-Bamman 2001). To tell stories, to do their socio-political work and to stage realities - including of Sáminess - the theatre companies have commissioned works in Sámi language. Then they have staged them with all the "Western" theatre values; they have translated existing plays into Sámi; and their creators have incorporated diverse artistic modalities, genres and expressions that today are important to Sámi people, including dance. Some stage plays, dance theatre productions and operas borrow from Sámi shamanism (Persson i2014).

I conceptualize the productions in terms of musicking, which refers to all the social interactions that go into creating a musical experience (Small 1998). I include in musicking the social processes that go into and lay behind staging various theatre values. Theatre values including and beyond music include dialogue, clothing and costumes, set design, props, lighting, sound effects beyond music and movement such as dance and blocking. ${ }^{2}$ In addition to music and artists' thinking about music, I highlight dance and visuality.

2 Blocking refers to how an actor positions him or herself, as well as how he or she moves, onstage. 


\section{Theoretical and methodological approach}

When approaching the musicking, I take inspiration from North Sámi scholar Harald Gaski. Gaski theorizes the place of cosmopolitanism in Sámi studies. This includes cosmopolitan theory's origin in the Greek notion of kosmopolites (citizens of the world) and subsequent development by European philosophers (by Kant, Levinas, Derrida and others) and scholars of cultural cosmopolitanism (for example, Appiah and Werbner). Gaski observes in his essay "Indigenism and Cosmopolitanism: A Pan-Sami View of the Indigenous Perspective in Sami Culture and Research" that in contrast to Indigenous North Americans, who have been more "aggressive" in struggling to indigenize Native American Studies so that it is a place for Indigenous North Americans (Gaski 2013: 116), Sámi have been more welcoming of diverse cultural, ethnic, and racial perspectives and backgrounds of scholars.

So far our scholarship has not distinguished itself to any appreciable extent from Western scholarship in approach or choice of methods. It's been more about getting Sami perspectives into research-i.e., Sami empiricism-and not, to the same degree as in North America and Oceania, a question of taking our own epistemology as a point of departure, of theorizing from our own knowledge traditions. Such theorizing, Sami scholars have argued, may proceed not necessarily in place of the Western tradition, but rather in addition to it: the aim has not been framed as an "either/or" question, but rather as a "both/and" proposition. (Gaski 2013: 116)

This Sámi perspective, in principle, recognizes "a difference between research politics and research practice" (Gaski 2013: 116). Gaski speaks for cosmopolitan theorization as one possible approach to Sámi culture also by non-Sámi, like me. An inclusivity of people and process also resonates with the artists' understandings and performances from the period studied here. Frequent cross-cultural use of intangible expressions by Sámi artists is another theme that comes up in my analysis. Sámi music and theatre performances often address two audiences-a Sámi and an international one-via culturally hybrid expressions (Gaski 2008: 355-358). These often (but not always) constitute a "double communicative" gesture (of storying and musicking function and aesthetic) in which certain meanings are intended for local Sámi audiences only and others for non-Sámi while still other meanings are broadly shared (Gaski 2008: 350). I work within a Sámi ethos and ethics partly described here; I discuss most the contents intended for non-Sámi.

The article draws on ethnographic research that I conducted among Sámi artists and at the two professional Sámi theatre companies in Norway, Beaivváš Sámi Našunálateáhter and Åarjelhsaemien Teatere, most intensively between 2012 and 2015 and 
intermittently since then. The fieldwork, consisting of performance ethnography and interviews, is supported by archival research in the companies' audio-visual archives, including on productions before 2012. The personal audio-visual archives of Ada Einmo Jürgensen (a choreographer and theatre director; Sea Sámi) are instrumental to my research.

After reflecting on Indigenous cosmopolitanisms, I variously examine, among other productions, the joik operas The Frost Haired and the Dream Seer and Allaq; the dance theatre productions Eatnemen Vuelieh and Gieje; and the stage plays Silbajárvi and Almmiriika. I discuss premières of these productions created by the theatre houses in Norwegian Sápmi as well as a remount of Frost Haired. Addressing specific theatre productions allows me to remain faithful to the storying of their musicking, and to observe configurations of cosmopolitanism in context. I selected the performances using what Tia DeNora calls the "cherry arranging" ${ }^{3}$ method of representing qualitative research data. "Cherry arranging" means that representative examples of a larger body of research data are analyzed and published on (DeNora 2021). The voices of Sámi musicians and theatre artists feature prominently in my text. I intend them to purposefully reflect Sámi collaboration and feedback, or Sámi mediations (Gaski 2013: 118) within my research process.

\section{Indigenous cosmopolitanisms}

The term Indigenous cosmopolitanism combines cosmopolitanism-which highlights "the cultural dynamics of what might otherwise have been understood as globalization" (Forte 2010: 3) -with the term Indigenous, which refers to the approximately 370 million people across 70 countries globally who self-identify as Indigenous. As defined at the UN Permanent Forum on Indigenous Issues, the heterogeneous concept of Indigenous means people self-identifying as Indigenous; continuing historical pre-settler societies; strongly linking to territories and natural resources; maintaining distinct social, economic or political systems plus languages, cultures and beliefs; having a non-dominant position in broader society; and resolving to sustain ancestors' environments and social systems (UNPFII Factsheet n.d.; discussed further at Harrison 2020: 28). Because Indigenous is a word used to politically unify such groups for example at the United Nations where Sámi have been active, it can be said that "there really can be no indigeneity without cosmopolitanism, and vice versa" (Forte 2010: 11).

3 This is a word play on "cherry picking," which refers to choosing the best. 
In Sámi theatre, some musicking engages Indigenous people specifically, for example Sámi, or different Indigenous groups together, in one opera Sámi and Ainu (Indigenous Japanese) in an overall expression of Sáminess. Other musicking engages Indigeneity together with one or multiple geographic regions. I will identify related examples of pan-Indigenous and pan-Arctic cosmopolitanisms.

I also highlight examples of vernacular cosmopolitanism, which refers to everyday, lived cultural practices (Werbner 2020; 2006 ). I point to manifestations of cosmopolitanism whose conceptual framework - for example, vernacular or pan-Arcticmay not necessarily be Indigenous, just as the music in Sámi theatre is not always Indigenous as I illustrate in the second-last subsection.

I focus most on rooted cosmopolitanism. Root is a central artistic concept in Eatnemen Vuelieh and can be found in many productions. Rooted cosmopolitanism often overlays with the previous adjectival cosmopolitanisms. It is particularly suited to describing Indigenous artists connecting to place (Proulx 2010 and DeLugan 2010, extending Appiah 2006). Music and musicking in Sámi theatre frequently convey a rooted cosmopolitan linked to specific geographies in Sápmi. My examples of rooted cosmopolitanism additionally have aesthetic "roots" in ethnicity, nation and spirituality, themes relevant across cultures but relevant to Sámi in particular ways. I observe limits of using adjectival cosmopolitanisms as an analytical tool, including in Allaq.

This article builds on music anthropological and ethnomusicology research on varieties of cosmopolitanism (Webster-Kogen 2014; Perman 2012) through describing music-theatre examples. The examples broaden knowledge of what cosmopolitanisms can be in Indigenous musicking. The (Indigenous) cosmopolitanisms have roots in Sámi history and historicity while implying transnational exchanges. My analysis extends a growing body of scholarship conveying how indigeneity and results of transnationalism are not separate or opposed but intertwined and inseparable (Levine and Robinson 2019; Forte 2010). I reference aspects of cosmopolitanisms broadly shared in an echo of Sámi scholars' and theatre artists' very point in engaging cosmopolitanism: to communicate across cultures and contexts (Gaski 2013 ; 2008).

\section{Case studies from Norwegian Sápmi}

\section{Gieje}

Gieje ("Footprints" in South Sámi) is first in a series of two dance theatre works (the second being Gon) directed and choreographed by Ada Einmo Jürgensen and staged 
by Åarjelhsaemien Teatere. Here I will interweave a description and my analysis of Gïje. As performed at the Riddu Riđđu festival in northern Norway in 2008, Gieje begins as five characters enter the performance space-a grassy area outdoors. They dance as if they are finding a place to camp. Dressed brightly, they carry bags. These are female dancers. Jürgensen commented, "They move as if they are breaking land, and marking the area. They show to each other that this is my area, this is my movement. This is or I am bigger and better" (Jürgensen i2014).

The dancers "explain" to the audience using gibberish, then say almo, which means "man" in South Sámi. One male dancer enters. All the dancers toss metal rods, perhaps three metres long each, into the space. They fall on each other in an irregular pattern. The rods are inspired by the Japanese mikkado game, where the point is to take out one stick without moving others.

Music is heard on a radio, then the news in Sámi. The male actor drums a rhythm on wood while the female dancers step in the spaces between the "mikkado" sticks. One of the dancers moves a stick. Therefore, she is out of the game.

In addition to the Japanese reference, the costumes, props, and music have a cosmopolitan edge. Marking Sámi ethnicity, some of the dancers wear Sámi-style leather boots with toes upturned. Yet the dancers each wear many kinds of clothes, each piece of which might be beautiful, but none of which go together as an outfit. Jürgensen recalled that this was like her Sea Sámi aunts, from Norway's northern seacoast, who were poor. Yet if they came across some fetching clothing, they would wear it, no matter if it matched their outfit or not. "The compilation becomes a style or an expression" (Jürgensen i2014). The clothing might be made anywhere in the world-for instance artificial fabrics produced in the third world-but Jürgensen interpreted it as used by Sámi in a specific region and circumstance. I interpret her interpretation as rooted cosmopolitan. The same applies to Gïeje's props such as a shopping cart and plastic bags. The production used a djembe and frame drum, but not the type of frame drum Sámi shamans traditionally played.

Jürgensen's chosen costumes, props and drums can differently be related with cosmopolitanism in how they reflected her thoughts about Sámi groups that suffered cultural assimilation during colonization. For the Sea Sámi or groups with extinct Sámi languages (such as the Kemi Sámi or Akkala Sámi), Jürgensen said, "the Sámi nation has been built on scratch (nothing) because so much was taken away from us." One "can use many metaphors to describe nation-building of the Sámi" (Jürgensen i2014). This was, simultaneously, an ethnic Sámi cosmopolitanism. 
Joik takes at least five guises in Gïeje as the work continues, most of which play into interrelated varieties of the cosmopolitan Sáminess of the work's music and musicking. Firstly, Gïeje is structured "like a joik" (see also Diamond 2011: 44; Harrison 2019). This is reflected in the work's dramatic arc and phrasings. Regarding arc, Jürgensen commented, "Were Ibsen used, it would start at a starting point, have a climax, and then have an ending. By contrast, joik is circular, goes on and on and on, it has an open beginning and an open ending" (Jürgensen \& Harrison 2016). In terms of phrasing, "In the joik you can pause wherever you want. You can pause and then you can start again. One day you are out of breath, one place, and another day you are out of breath another place, where you have to light a cigarette, or something happens around you and then you can continue" (Jürgensen i2014). After one player is "out" of the mikkado game, there is one such a shift in direction: The performers start playing with other props like blankets. They move as if to organize their space. Everything can be used. The bags are hung on the mikkado-like sticks, for example. A thin cloth is strung between two sticks. Jürgensen commented, "If there is an interruption, big or small, everything can take a different direction and then you can go back to what you are doing" (Jürgensen \& Harrison 2016).

Secondly, joik is presented in historical ways, in which a joiker expresses a sense of a phenomenon in his or her surroundings. In a following scene, two female dancers become like animals. They sniff and smell. One acts as if "I like your smell" (Jürgensen \& Harrison 2016). One of the dancers dances then sings a North Sámi wolf joik. The women behave like wolves, continuing to smell. Then the other dancer sings a South Sámi wolf joik. Rooted cosmopolitanism can be heard. It has its roots in specific Sámi language areas and geographies, which include their animals.

Thirdly, one joik performance is a fusion joik which blends different styles of joik. The two dancers sing the North and South Sámi joiks at the same time. This constitutes fusion, because the musical features of joiks are distinct roughly according to the geographies of the different Sámi languages (from northern Norway to northern Russia). The term "joik dialect" is sometimes used to identify different styles of joik that roughly correspond with different Sámi language speakers and regions (see Jouste 2009; Moisala 2011). In Gïeje, the North and South Sámi joiks could be interpreted as expressing a cosmopolitanism rooted in Sámi languages and related (geographical) areas. As joik of the North and South Sámi sound together, this could also be a pan-Sámi cosmopolitanism. Yet djembe and frame drum accompany the joiking. The sounds of African Indigenous djembe could be interpreted in terms of pan-Indigenous cosmopolitanism, as well.

Fourthly, joik is used to comment on itself. One may say that the joik is joiking joik. Another scene in Gieje features one female dancer joiking while another female 
dancer plays frame drum - which again, is non-Sámi and could be Celtic or Native American. Whereas drum-types raise the possibility of pan-Indigenous cosmopolitanism, the singing could affirm it. Both women start singing the vocables "hey ya ha," which are used both by Sámi and Indigenous North Americans, for example. All the actors join the women in singing, combining different tones in a cluster. Jürgensen commented, "The joik always ends in an argument. Sámi always argue, 'No, joik is not like that around here"' (Jürgensen i2014). ${ }^{4}$

Fifthly, Gïeje's dancers implement Jürgensen's method for creating dance theatre, called symbiosis (detailed in Harrison 2019: 34-39). Symbiosis is a way of thinking about joik and deriving dance performance from it. The aim is to be dancing something in the same spirit one would joik. This differs from dancing to joik or other sound (Jürgensen i2014). Examples of symbiosis in Gïeje are bear and moose joiks, which are danced with no sound. Jürgensen explained the process for making these "body joiks":

I played for the dancers a bear joik and a moose joik. I did tell them what kind of joiks these were. I let them play with the movement that came out of the joik, to dance the joik not to the joik. We took the joik away and we just kept the movements in a body joik. Then we put a dramatic setting to put them together- the bear attacking the wolf. The dancers all the time had to keep in the feeling of the joik. They couldn't just change and be a bear, for example. Very often when we were doing the routine for the bear and the moose, they would have to go back and listen to the joiks to get the right feeling in the body. (Jürgensen i2014)

The dancers' rehearsal and development processes involved listening and listening again to joiks in order to maintain the feeling of joik in the movement.

In symbiosis, joik informs dance, but also dance may inform joik. The openness of the term recognizes that there are many ways in which joik and dance can feed into one another, leaving room for many explorations of possible creative relationships. In Eatnemen Vuelieh, for example, Inga Juuso joiks dance movements to come.

4 Besides Gïeje, many Sámi productions have articulated different types of linguistic and ethnic (rooted) cosmopolitanism. For examples from Beaivváš Sámi Našunálateáhter, Arya Leena blended Sámi and Tibetan traditions (Gunnarsson i2012; Kvernmo 2014); Mun lean Inanna or I am Inanna mixed lyrics from ancient Sumer together with Sámi language, Japanese-inspired movements and costumes inspired by the Middle East and various Indigenous peoples globally; and Lorca's Blood Wedding mingled joik with Andalusian flamenco. Some of these cosmopolitan productions indexed national roots as well, such as in Tibet and Spain. 
The silently danced joiks in Gïje resonate with one method that Frode Fjellheim (South Sámi)_Jürgensen's longtime creative partner for developing and implementing the symbiosis method-uses for composing joiks. He creates joik melodies from the sounds of language. It could be the English language phrase, "Trondheim is a nice city," or phrases in other languages. He takes away the words, then builds musically on their sounds' rhythms and pitches. Sámi language can be used in this way during the creation of traditional joiks. Fjellheim said, "Sometimes I just open a book and start reading, and I'm just improvising a melody as I'm reading the book and record it" (Fjellheim i2015). In the creation of dance through symbiosis, the joik sound may be stripped from movement.

Gïeje also includes a sound performance made using homemade "instruments" from anywhere and everywhere available, in other words their cosmopolitan provenances. The dancers use sounds from the audience, and since this was initially an outdoor performance, blowing wind, in order to inspire the musical rhythm. They first play, as percussion instruments, props that they find around the performance area, for example a cooking pot, a food tray, a bucket as well as a rattle and drum. Later, they circle in the air electricians' plastic tubing, which makes high-pitched whirling noises. Gïeje's music, sounds, and other theatre values evidence a "culturally open" and cosmopolitan Sáminess.

\section{The Frost Haired and the Dream Seer}

Whereas Gïeje engages the Sea Sámi and South Sámi language groups, The Frost Haired and the Dream Seer deals with North Sámi environments particularly of the traditional livelihood reindeer herding practice. Frost Haired (for short) has been described as "a dream play-wherein a young reindeer herder is visited in a dream by a sage from ancient times. The sage imparts forgotten wisdom to the young man and paints a vision of chaos and destruction lest Man forgets that he is but a tiny part of the Universe and that he is subordinate to Nature" (Gunnarsson i2012).

The play includes diverse cultural influences at the levels of the script including its dramatic conventions, visuals, costumes, blocking, sounds and music. Cosmopolitanism in this musicking extends at least from Sápmi to Japan.

Beaivváš Sámi Našunálateáhter produced the play in 2007 and remounted it in 2013. The production projected its Sámi text, with appropriate language translations for performances in Sápmi then national (Norwegian) and international tours, on a screen behind the stage together with images of Sápmi nature, with fells and reindeers, in different seasons. 
These performances of Sáminess reflect the international history of the play and cosmopolitan interests of its creators. Frost Haired was written by Sámi cultural icon Nils Aslak Valkeapää (North Sámi, Finland; called Áillohaš in North Sámi). It was first performed by him and his artistic team in 2001, in Sapporo, Japan, as a recital during the city's winter festival, shortly before his death. Joiks created by Valkeapää's team were interspersed with poetic text by Valkeapää (translated from Finnish then) read in Japanese, by Junichiro Okura.

The 2007 and 2013 remounts combined Valkeapää's poetry with dramatic conventions of Noh theatre, including from the book of Zeami, a 15th-century book about the principles of Noh. The principles include the conventional Noh characters of the shite, the main character, and waki, a storyteller figure. Director Haukur J. Gunnarsson explained,

The waki is a humble person or a pilgrim. In this case it is a reindeer herder following his herd. The shite, the main character, is an image of what you can interpret as the noaidi, a [Sámi] shaman from old times, who has come to reveal to the young reindeer herder the old wisdom, which he wants him to carry on. In the end the Dream Seer gives his noaidic power to the young reindeer herder, who then in a way takes over his role and wisdom. (Gunnarsson i2014)

Other aspects of Noh in The Frost Haired and the Dream Seer include the show starting with an empty stage. There is the constant presence of a chorus: joikers who are also the actors as well as live musicians. However, Gunnarsson and choreographer Indra Lorentzen decided to do something more than in Noh when the chorus enters the stage and takes its place. Usually in Noh, the entrance is silent and non-interactive. For Frost Haired, the characters entered one by one, audibly greeting the audience in North Sámi language. "They represent the spirits of nature and also the helpers of the Frost Haired. They are much more active than the chorus in Noh theatre," Gunnarsson explained (Gunnarsson i2014). This action of the musicians and actors rooted them in Sápmi whereas the sage Frost Haired represented an environmentally aware, historically informed and culturally continuous Sáminess.

Noh also influenced the choreography. According to Gunnarsson (i2014), Lorentzen "didn't try to recreate Noh-style movements, but she used the atmosphere of Noh, the contained energy of the Noh theatre actor. The choreography is an original creation." She used actors' movements to convey the atmosphere of nature, reindeer and wind. "In a way," Gunnarsson observed, "the text is choreographed [also]. There are 
scenes of free spirits in the background [against projected photographs of Sápmi] nature, reindeer and the wind [in the landscape] while Frost Haired is speaking to the reindeer herder [and] there's no music" (Gunnarsson i2014).

Costumes also give a Japanese-like atmosphere as two female actors wear kimono-like silk costumes. Yet the visuality is also Indigenous Japanese or Ainu. Frost Haired wears a bear design derived from bear mythology of the Ainu. Sámi also have bear myths. Another costume features an Ainu owl design. ${ }^{5}$ Gunnarsson elaborated, "Valkeapää went to the north of Japan because this is where the Ainu people come from. There was a connection there" (Gunnarsson i2014). Further extending the Ainu content are light projections to the side of the stage, based on Ainu patterns. For the male actors and members of a live band, costume designer Berit Marit Hætta used also the basic cut of Sámi traditional dress, gákti (in North Sámi). Thus, the visuality of this theatre production combined Japanese dress with Ainu-influenced light projections and costumes as well as the Sámi gákti. The visuality of Frost Haired had Indigenous cosmopolitan roots both in Ainu and Sámi cultures. A critical mind might question what it means to have roots in specific cultures without authorship in those cultures. A detailed consideration of such ethics is beyond the scope of this article. The Sámi artists I interviewed saw such borrowing as unproblematic within their ethos of cultural openness which honors Sámi artists' cross-cultural connections and trusts them and their artistic collaborators, as arts experts, with honoring the necessary and appropriate ethics. Such an ethos also shapes, for example, how in the Sámi music industry, many Sámi musicians include musicians and music genres from other cultures (Chen in progress). This reminds us that morality is always culturally located.

The music, essentially the same in 2007 and 2013, consisted mostly of joik-jazz fusions earlier created, performed, and recorded by Valkeapää together with other musicians. Frost Haired especially used joiks co-created by Valkeapää and Esa Kotilainen (North Sámi, Finland), then recorded in the 1970s and '80s.

Gunnarsson hired Mattis Hætta as a joik consultant in order to select joiks composed and recorded by Valkeapää. Hætta chose the joiks, Gunnarsson said, based mostly on "the moods of the scenes; more the melodies than the text[...]. In a way, we ignored the text or the lyrics over the sounds because we were using the melodies as [a way of] creating an atmosphere around a situation, [an] emotion of a scene" (Gunnarsson i2014).

5 Other examples of Japanese influence in productions of Beaivváš Sámi Našunálateáhter include Nárukámi (1991), a Japanese kabuki play adapted to Sámi mythology; Boaresbártnit (Batchelors 1995) that combined Japanese comedy with Sámi storytelling; and Nikio (2008). 
Different from the costumes, movements and musician/actors' greetings of the audience, the music did not integrate any "Japanese" sounds according to music director Roger Ludvigsen. When I asked Ludvigsen whether he intended the use of flute, played by Patrick Shaw Iversen, to sound Japanese in any way, the answer was, "No, we didn't think of that" (Ludvigsen i2013). Ludvigsen played guitar while Kotilainen played synthesizer. Thus, the musical sound foregrounded Valkeapää as much as possible. It sonically rooted the broader cosmopolitanism of the production in his music. Ludvigsen elaborated, "Basically the arrangements [in the play] are the same as they [were] 30 years ago. We [were] thinking [...] not to change [...] much, to make new arrangements. We wanted to keep [the sound] like it was" (Ludvigsen i2013). Kotilainen noted that the melodies were the same as in the 1970s, as was his instrument (synthesizer) and the musical form for many of the joiks, however improvisations were "a little bit different" from the "70s and "always different" from performance to performance. There were other minor changes, for example, using a different key for a new singer or choosing not to use any instruments in one case.

No instrumentation was used, however, for a joik thought to be Valkeapää's mother's joik to Valkeapää (sung by Mary Saare). This means that the joik was created by Valkeapää's mother for Valkeapää, it is in the genre of a person joik, and as such, it belonged to Valkeapää. Another joik likewise had no instrumental accompaniment (and was performed by Ingá-Máret Gaup-Juuso in 2007, replaced by Ingor Ántte Áilu Gaup or Áilloš in 2013). The monophonic joik strongly indexed North Sáminess due to the North Sámi joik dialect being associated with its corresponding language and culture area. Yet as music scholars know well, music styles and genres shift and change all the time, including joik, whose practitioners from across Sámi and sounds are nowadays in constant contact and may influence one another (Gaski 2008).

When it comes to the polyphonic joiks, featuring voice with instrumental accompaniment, I'd like to peel back exactly how Valkeapää's sound (Ramnarine 2009) could be considered both rooted and cosmopolitan. Kotilainen and Ludvigsen described to me in interviews the cultural mix in Valkeapää's joiks, from the perspective of compositional process. Valkeapää had a "very, very open mind," Kotilainen explained. When making new joiks, Valkeapää sang the vocal line. He usually composed the joik melodies although sometimes he collaborated with others on this. For joiks used for Frost Haired, four out of the 13 pieces are collaborations. The joik melody was ready or "fixed" before an improvisation session, then other musical material was built on top of that. Valkeapää was then "very free to experiment with sounds and arrangements" (Kotilainen i2013). In practice, Kotilainen improvised on keyboard, and the other musicians with whom he collaborated were free to join in creatively with their own ideas. The instrumental and synthesizer effects surrounding Valkeapää's 
joiking came from other musicians, with Kotilainen making a foremost contribution through his extremely skillful keyboard playing and sound manipulations.

The strongest non-Sámi influence in Valkeapää's sound, which as mentioned was collectively generated, was free jazz-developed in 1950s and '60s USA. According to Kotilainen, his free-jazz focus was inspired by a popular song from the early 1970s performed by Seppo Paakkunainen and Edward Vesala of the band Karelia. The song combined free jazz, drum and joik. Subsequently, Valkeapää took his music work in this new direction. In 1977, Paakkunainen, Kotilainen and Valkeapää met when rehearsing for, and then performing, a radio concert in Helsinki. They collaborated so well on joik-jazz fusion music that they continued their work including through the DAT record company in which they were all involved (Kotilainen i2013; for a history of DAT, see Hilder 2014: 164-167). Their forthcoming recordings can be interpreted as rooted cosmopolitan, or Indigenous specifically North Sámi cosmopolitan, in combining the North Sámi joiks with free jazz, a now-globalized music genre of American origin.

Valkeapää is renowned for his collaborative, ground-breaking recordings and performances of what is today called "new joik" or "modern joik." Hilder defines new joik as "music based on 'traditional' [joiks] or 'traditional' joik practice, which are negotiated to fit with 'Western' popular, jazz, and classical musical practices, such as tuning, rhythm, meter, and forms like popular song, as well as incorporating instrumental accompaniment of different kinds" (2014: 85). Valkeapää's joiks mostly refer to nature including places and animals, but sometimes also people, which are all traditional or historical joik subjects. In such ways, Valkeapää's joiks' sounds and subjects are rooted in Sápmi ethnicity (especially North Sáminess), regions (particularly the North Sámi region and Sápmi) and environments (for instance, northern Sápmi, but also a variety of places implied by globalized music genres). Various aspects sound a rooted Indigenous cosmopolitanism and cosmopolitan Sáminess while others point to transnational routes of music genres as part of recent Sáminess.

Kotilainen and Ludvigsen noted that reception of Valkeapää's joiks could be special for Sámi because many Sámi today know joiks recorded by Valkeapää in the 1970s (Kotilainen i2013; Ludvigsen i2013). Most Sámi viewers could take a deeper feeling of "rootedness" away from the production, also knowing for instance that "Sámi Eatnan Duoddariid," the first joik used in the play, joiks the tundra of the North Sámi people and their reindeer (Kotilainen i2013; Ludvigsen i2013), or that the joik "Biegga" refers to the wind experienced by both (Gunnarsson i2012). Sámi audiences would likely recognize these roots in the natural environment or people, especially Sámi from specific generations and places. Joik references are very specific if you are a cultural insider, for instance, as mentioned, one of the monophonic joiks was Valkeapää's mother's joik to Valkeapää. 
Additionally, Sámi audience members would likely recognize roots related with the construction of a pan-Sámi ethnicity - across Sápmi in today's northern Norway, Sweden, Finland and Russia - as well as an asserted pan-Sámi nationhood. Joiking Valkeapää's joiks, broadly, has been used in events that bring together Sámi from different languages and geographies. The events promote feelings of pan-Sáminess and nationhood, both in Sápmi and in the Sámi diaspora of the Nordic countries' southern urban centers. For one example, to celebrate the 70th anniversary of Valkeapää's birth in 2013, joikers from throughout Sápmi (including Johan Anders Bær, Ulla Pirttijärvi and Niko Valkeapää) performed Valkeapää's joiks as a concert both in Inari and Helsinki, respectively in northern and southern Finland. The performance unfolded in front of projections of Sámi poetic texts and Sápmi nature-photographs. Frost Haired took the same approach musically and visually (with relevant text-translations), including in tours throughout the Nordic countries as well as Iceland, Japan, India, Nepal, and Bangladesh.

\section{Allaq}

The joik opera Allaq ("Brown Bear" in Greenlandic; produced by Beaivváš Sámi Našunálateáhter) tells of a young Sámi woman who is a quivitoq. Quivitoq, a Greenlandic Inuit term, refers to a person who has too much power due to knowledge potentially damaging to community. Consequently, the Indigenous group to which she belongs has exiled her to a hidden valley. It has also sent her grandmother there to die due to age and illness, mimicking a historical practice. The story is set in a time of widespread environmental devastation in which poverty-stricken Indigenous people neither have food nor clean water. In the hidden valley, Allaq learns to "listen" to ancient ways, which the joik opera illustrates through the metaphor of her grandmother teaching her to "listen" to singing stones. Allaq becomes a bear's lover. However, a male from her community kills the bear and rapes her.

Allaq by Cecilia Persson (director, South Sámi Åarjelhsaemien Teatere) concerns various, broadly shared, kinds of violence. Persson evokes environmental devastation and gendered violence indirectly as a pan-Indigenous issue, through a fiction woven of myth, history, and story. The disaster theme at the beginning was intended to mirror Shakespeare's Harvest (Persson i2014).

The story spotlights elements of Indigenous culture from across the Arctic: a Sámi bear myth; Athabascan and Greenland Inuit histories of being left by or leaving a tribe to die; Athabascan shamanism; and journalists' stories of stones that "sing" as they move on the ground in southern Greenland. These ethnicities index a pan-Indigenous and pan-Arctic affinity of Sámi as an expression of Sáminess.

The costumes also take inspiration from different Arctic Indigenous groups. Designer Berit Marit Hætta said that she intended the costumes' colorfulness to inspire 
hope. She "noticed how people living in extremely poor countries, who have in a sense had to surrender to their environment, nevertheless dress up and decorate themselves. They have not lost their dignity and zest for life although they may be in need of everything else" (Lehtola \& Magga 2011: 48). While the costumes may be considered pan-Arctic Indigenous cosmopolitan, Hætta related the costumes' relevance to economically marginalized peoples, which, as Jürgensen observed, includes some Sámi.

The staging and lighting offer additional Sámi content. Three low wooden arches on the stage mimic designs from duoji or Sámi handicraft. As Allaq's grandmother dies, she appears, thanks to video projections, to climb the Milky Way. This reflects Sámi beliefs about what happens after death.

Extensive art music composed by Kristin Mellem drew on her background as a classical string player and a Sámi. It expresses her western as well as pan-Arctic affiliations as a Sámi and, thus, her Sáminess. For this pre-recorded music, Mellem performed violin, viola and cello whereas other musicians played synthesizers, organ, prepared piano, and percussion (Beaivváš 2010). She also incorporated many drum sounds. She intended the drumming to echo sounds shared by Sámi, Inuit and Athabaskan peoples and beyond (however, the play did not incorporate widely different drum rhythms, timbres, styles and -types). She intended a steady "drum rhythm" played on cello in the bear-hunting scene to suggest shared bear rituals among circumpolar Indigenous groups. Mellem (i2014) commented, "I wanted to relate to Sámi music, but not too much. I wanted to introduce other elements to open the music in terms of time and space." The steady rhythm in somewhat flexible time sounded "in the spirit of" a bear: "The bear is so flexible and strong and it's not slow. It's very accurate I think" (Mellem i2014).

Because the singing stones are in Greenland, and Greenland is about $90 \%$ Inuit, Mellem intended music she composed about the stones to reference Indigenous peoples, not "only" the environmental theme of the plot. Mellem took an Indigenous view to the stones, perceiving them and creating music about them as animistic and living witnesses to history:

It is like a magazine of history inside these stones. They have seen everything coming and going. They have seen animals, nature, people coming and being born and dying and all the generations coming. They have seen it all and, in a way, they are just watching. They have the wisdom, but they don't interfere with anything, but they know everything. (Mellem i2014) 
In this way, Mellem understood her pan-Indigenous, pan-Arctic, and western cosmopolitan sound as expressing Indigenous epistemologies concerning the natural world, particularly elements of the natural environment understood as living beings.

Her use of joik indexed a cosmopolitanism rooted in Sámi ethnicity and her specific Sámi language and geographical area. The beginning of "Allaq's Joik," sung in North Sámi and joik vocables, uses intervals that Mellem hears as customary for joik in her area: perfect fourths and fifth intervals. Then it changes to uncommon intervals: a major third and augmented fourth or diminished fifth. "The beginning is like a joik and then I go in another direction," she explained. Because it is the character Allaq's joik and Allaq is a Greenlandic name, but the joik obviously is Sámi, the scene presents pan-Arctic Indigenous cosmopolitanism. The music also is vernacular cosmopolitan in that the joiker in the 2010 première, Ingá Márjá Sarre, joiks in her everyday artistic life while her accompanying keyboard (synthesizer) player and percussionist also perform music daily. Mellem composed the music, an everyday professional practice for her. But the musical cosmopolitanism is also something else, as the joik is adapted to diatonic, western tonality, thus departing from a historical Sámi pitch orientation. When cosmopolitan hybridity evades cosmopolitan theory's very conceptualizations - for example, through not being clearly identifiable by one adjective or another-this challenges the precision and viewpoints of the theory itself.

Mellem further intended her musical score to be like a joik in ways that all audience members, be they Sámi or non-Sámi, could potentially understand (Mellem i2014). Unlike the creators of Frost Haired, she did not seek to produce two sets of musical legibility, one for Sámi and another for non-Sámi. Rather, she attempted to translate between the two, by abstracting aspects of joik and Sámi ritual and then composing art music engaging those ideas.

For example, to represent landscapes, Mellem recorded actors' voices at a whisper to sound as if they are remote. She also used higher and lower pitches to mirror the undulations of mountain peaks, when composing music about the singing stones. Mellem also sought to convey vibrations of people and environment central when creating music like joik. Yet how to listen to such references is culturally specific to Sámi in ways that she felt a need to translate for culturally diverse audiences who enjoyed the play, which toured the Nordic countries, and for Allaq's music album, available internationally (Beaivváš 2010). She explained:

If you know about joik, then you also know the setting around it. You can listen to it because you have this knowledge already about places in nature or family or whatever [the joik engages]. If you are not familiar with joik 
tradition then you need something, like a landscape, to understand. So, I tried to find sounds and ways to help the imagination. For me, nature is connected to something holy. Not always and not every day, but there are places I can go to really have the feeling of a strong vibration. (Mellem i2014)

In her compositions, Mellem said, she joiked vibrations of landscapes and beings by combining what she perceived as "light" with "dark" or "scary" elements (Mellem i2014).

Musical spatiality, timbres, pitches, and textures were other means through which Mellem worked to use art music composition to translate joik ideas for non-Sámi listener-reception. Darker elements, for her, included "dark" timbres with higher quantities of lower partials and low pitches as well as drones (Mellem i2014). She used such sounds in scenes about environmental devastation and the violent killing of the bear. She represented the bear's death with a low drone whose dark timbre, produced through electronic music programming, sounds like a low growl. After an initial iteration of "Allaq's Joik," a subsequent iteration of its melody begins very softly and timidly, then turns voluminous and thick in texture: "very violent, like fifty elephants stepping on top of this little melody. It's theatre." This contrasted the lighter-textured, "normal” start of "Allaq's Joik" (Mellem i2014).

Mellem described the use of "light" and "dark" sounds (Mellem i2014) as more than adhering to classical musicians' everyday categorizations of such sounds, which she did, and more than underscoring, a technique used in Western-style theatre where sound illustrates or conveys the mood of dialogue or scene. She understood the sounds as engaging Sámi shamanistic ideas from her family and background.

I wanted to try to go closer to this "holy" feeling. In Christianity, we learned that God is light only, but maybe, the holy - vibration is everything - is also darkness, both forces. That's why it [Allaq's music] shouldn't be only beautiful. It should be this dualism, a little of both. As a human, you understand that you are quite small, but you are part of something very big and that is also maybe what makes you so valuable because you are really in a chain with other people but also connected to nature and, really, part of this holiness. The nature in this human person is part of nature and because of that, the human is born to be part of this development or this circle of life and change. (Mellem i2014) 
Mellem explained that she worked intuitively from her background of Sámi traditional spirituality. Even though she grew up in a family that lost its language and as Laestadian, ${ }^{6}$ part of her family tradition was shamanism.

It's also part of my family tradition that, if there are five or six houses, there would be, in more than one house, people who know how to cure this and that. It would be using elements that we think of as shamanistic, using soil, using metal, using, asking. These ways of doing things will also be connected to the Lord's prayer. People get well. You cannot say that you don't believe it because you have seen it so many times. If a person has a problem that modern medicine cannot deal with, then we make a phone call to these persons who know who can do it. We are still in a tradition that deals with this. (Mellem i2014)

For this reason, Mellem drew on understandings taken from Sámi shamanism including the "light" and "dark" nature of vibrations (Mellem i2014), and humans" connections in the natural world. Within her Indigenous-cosmopolitan music in which she intended to translate joik meanings across cultures, Mellem emphasized Sámi spiritual and shamanistic roots that held personal meaning for her.

\section{Eatnemen Vuelieh}

Eatnemen Vuelieh ("Songs from the Earth" in South Sámi) is an Åarjelhsaemien Teatere dance theatre production, with overall creative design and direction by Ada Einmo Jürgensen, which premièred in 2007. It consists of musical performances that combine joik and sung Christian hymns (original vocalists: Inga Juuso, Frode Fjellheim and Sven Henriksen), accompanied by cello (Alsos Strand) and synthesizer (Frode Fjellheim) as well as a dancer (Therese Einmo Jürgensen) and video projections (by Håvard L. Nystad).

The recital-like production has two main themes, one being the metaphor of the root. Dance and screen projections represent roots of trees and other vegetation whereas joiks could be understood to evoke different kinds of Sámi roots. Jürgensen described her artistic intention of using the root metaphor: "Where does joik come from? Does it come from 'roots'? Does it come from ornaments, meaning the impulse to decorate, like with the designs of Sámi handicrafts?" (Jürgensen i2014). The dancer, wearing a white bodysuit with black root-like designs on it, moves along the

6 Laestanianism, also called Laestadian Lutheranism or Apostolic Lutheranism, refers to a pietistic Lutheran revival movement of Christianity. Lars Levi Laestadius, whose mother was South Sámi, founded the movement in the mid-19th century in Sweden. Laestadius proselytized among the Sámi, initiating a popularization of Laestanianism in Sápmi. Currently, Laestadianism has most followers in Norway, Sweden, Finland, Russia, and North America. 
floor in a winding motion, evocative of the reach of a root. Similar movements of the dancer, nearly naked, were pre-filmed and are projected on the largest of seven screens flanking the performance space. Roots, earthen colors, and water (necessary for roots to grow) appear in the video. Videography of a Sámi drum, highlighting the symbols typically painted on it, is projected on the largest screen at another time in the performance. Since Sámi drums were historically used by shamans, this indexes Sámi spiritual roots and shamanism. Stylizations of two drum symbols in white light also appear as projections on the screens and dance floor. The images move, encircling each other, and the dancer tries to "catch" (touch) both symbols with her feet at once. The dancer appears body-painted in black ink, with Sámi designs. The extensive body painting process, taking a whole night originally, was filmed then all the brush strokes were edited out. The edited film is another projection.

Eatnemen Vuelieh's second unifying theme is Christianity. Sven Henriksen contributed this concept. In production workshops, he remarked that among North Sámi, the joik may still be considered heathen when one cannot joik or drum in church, just as it was when suppressed by settlers during colonization (Jürgensen i2014). This is particularly true where there are concentrations of North Sámi speakers, like in Karasjok and Kautokeino, northern Norway. Officially today, the Lutheran church in Norway does not ban joik-in fact it is integrated into its hymnals, but Sámi themselves may discourage it in church. It is not the oldest and most "traditional" Sámi who oppose joik in church, but young Sámi (Fjellheim i2014). The Lutheran church was the Church of Norway until 2017, when Norway separated state and church. Thus, Eatnemen Vuelieh could be interpreted as bringing national and associated religious (Lutheran) roots together with different kinds of Sámi ethnic roots including of spirituality and shamanism.

Whether Eatnemen Vuelieh is a cosmopolitan expression can be debated. Certainly, Sámi experienced cultural assimilation through the church in colonial times and Christianity has globalized. But just as certainly, some Sámi have adapted Christianity as their own as well as developed sometimes strong opinions on what Christian music should be like, in their communities. In churches where joik has been banned and that have Sámi congregations, one can, nevertheless, "hear the joik within the hymns" (Fjellheim i2015). The show's musical director, Frode Fjellheim (South Sámi) explained,

They're using their voice in a way that is joik-like. Somehow the joik has survived in the church in these areas in this way. For at least the last 200 years, there has been a tradition for instance in Kautokeino in which people in the church sing hymns, but they sing them joik-like. If you ask them, they will deny it completely because they're not joiking, they're just singing the hymn. (Fjellheim i2015) 
Compared to hymnal singing in non-Sámi Norwegian churches, the Sámi pitch orientation or tonality is not necessarily diatonic and there are small sonic transitions including pitch slides from note to note. The tempo is comparatively slower.

North Sámi joiker Inga Juuso sung a hymn in this manner in the première, therefore. That performance, Fjellheim said, "shows the artistic intentions of this project: making these two worlds and putting them beside each other. We tried to create one expression in which you can see that the joik can be one aspect and the hymn can be another-they're not separate things" (Fjellheim i2015). Even so, Eatnemen Vuelieh contrasted, and drew dramatic tension between, state religion and Sámi roots in at least one instance. Henriksen sang "Herre Gud Ditt Dyre Navn og Aere," whose lyrics, published by Peter Das in 1715, explain Lutheran orthodoxy. They date from a period when Norway was under Danish colonization. People in their 60s and older today had to learn the song in state-funded grade schools, when Lutheranism was the state religion in Norway. Henriksen sung the second verse of the song using an extremely forced timbre that produced many overtones. A rhythmic keyboard improvisation by Fjellheim was accompanied by a projection of a historical text in Norwegian, which translates in English as "every beat on the drum is and always will be Satan's beat in hell" (Jürgensen i2014). Globally during colonial periods, it is commonly said in Indigenous communities that Christian missionaries, priests, and believers claimed Indigenous drums and shamanistic practices to be of the devil.

Otherwise, the music includes the Kyrie from Fjellheim's mass Aejlies Gaaltije (The Sacred Source - An Arctic Mass), sung by Fjellheim and accompanied by him on synthesizer and by the cellist. Henriksen also sang musical works included in Norwegian Lutheran hymnals including "Blott en dag" (Day by Day—of Swedish origin), "Det er en rose utsprungen" (Lo, How a Rose E're Blooming-originally German), "O bli hos meg" (Abide with Me-Scottish), and "Deilig er Jorden" (Fairest Lord Jesus-a Christmas carol frequently heard in the Norwegian church, but originally a Sicilian folk song), accompanied variously by keyboard and cello.

The Kyrie and hymnal performances combined joik with internationally popular Christian music. Although the entire mix was cosmopolitan, it had roots in Sámi sound through the ways in which joiking and joik were incorporated. It expressed Sáminess in this way.

In the performances of the Kyrie as well as the hymns, Fiellheim and Juuso interspersed joiking. This brought in different joik dialects as Fjellheim and Juuso joiked together. Like in Gïeje, one could hear styles of joik being different, as Fjellheim put it, "between families, between groups of families, between districts inland and on the coast" (Fjellheim i2015). A North Sámi joiking timbre and rhythm could be 
heard in Juuso's contribution, for example. At the end of "Deilig er Jorden" and to end Eatnemen Vuelieh, Juuso's rose her pitch by a quartertone so that it was no longer compatible with diatonic tonality. Then she started to joik using an incredibly different, perhaps older, timbre than that used elsewhere in the production. Often when repeating unaccompanied joik, a joiker shifts the pitch orientation upwards as well as, possibly, certain pitches. At one point, Juuso's rhythmic sensibility shifted so far from a rhythm track that the cello improvisation dropped out.

The joik performance, rooted in historical Sámi performance practices, was sometimes incompatible with a western pitch and rhythmic orientation of the instrumentalists and Fjellheim, who is classically trained. As musical director, Fjellheim led the ensemble into a joik ostinato (described below) in a way that mediated between Juuso's free-floating rhythm and regular rhythmic expectations of the cellist. Juuso then synched her rhythm with both, the hymn carried on and, as per Fjellheim's artistic vision for the music, Christian hymn and joik again easily coexisted in one Sámi, rooted cosmopolitan expression.

Fjellheim underlay "Deilig er Jorden" with a joik ostinato when he re-arranged the hymn for Eatnemen Vuelieh. Fjellheim and Juuso joiked the ostinato together, loudly, between verses yet quietly during the verses. About composing polyphonic arrangements of joik, Fjellheim said,

I combine the monophonic joik that just keeps going and going, and then add another layer on top, which is floating totally free, creating two very different dimensions in the music, where one is extremely joik-like, forming the basis of the composition. I compose something else around it, which very often includes elements from other musical traditions like classical music, pop or rock. (Fjellheim i2015)

The joik ostinato was later published as a choir score arrangement of the hymn and used in a co-composed piece, "Vuelie," for the Disney movie Frozen (see Ramnarine 2015). This music had a future cosmopolitanism, as well.

In new joiks like "Vuelie" that Fjellheim is globally renowned for creating, a repeated and monophonic joik melody that is both simple and complex musically. $\mathrm{He}$ explained:

Joik has a certain quality. It's strong and has repetitive elements. Simple, in a way, but also complex in the way that the melodic line is so interesting that it could be repeated many times. That is a challenge when composing joiks. That is what is a strong and fascinating element with the joik and several 
other Indigenous music traditions: to create something that is simple, but it can be repeated, and you can listen to it for a long time and still feel it's interesting. (Fjellheim i2015)

The point of adding additional harmonic and rhythmic material to the joik is to create contrast, but at the same time, "emphasize some elements of the joik" (Fjellheim i2015).

\section{Silbajárvi and Almmiriika}

I use Silbajárvi and Almmiriika to emphasize that not all Sámi theatre productions and parts thereof feature music genres initially of Sámi and Sápmi origin. This can be interpreted within the Sámi ethos of cultural openness including making intangible expressions from other cultures one's own. These musics are often part of Sámis' everyday lives, often for specific demographics, for instance art music aficionados or popular music-fans of a certain generation. As such, they offer additional examples of vernacular cosmopolitanism.

One such example is the stage play Silbajárvi (The Silver Lake; premièred by Beaivváš Sámi Našunálateáhter in 2012) with music composed by Håvard Lund. Silbajárvi is a psychological thriller written in North Sámi by Rawdna Carita Eira. Four teenagers go on a camping trip near Silver Lake in effort to look for a legendary ciehka or place hiding a silver treasure. Instead, they experience a nightmarish meeting with ghosts, including a woman who killed her sister's baby and who was said to spread the plague or black death among Sámi people. The play contains references to shamanism, such as reading the Lord's Prayer backwards, most apparent to knowledgeable Sámi viewers. It also engages other Sámi traditional beliefs around babies' deaths and their ghosts haunting, particularly how to conduct rituals to lay babies' ghosts to rest (Gunnarsson i2012).

Silbajárvi's music completely avoids the "holy" content (Mellem i2014) of Sámi shamanism. When I interviewed Lund, a non-Sámi Norwegian, he explained that he chose a musical theme for the play that consisted of a short phrase meant to mimic the sound of lapping water. Based on his personal compositional interests, he recorded a pianist improvising on the theme in the style of Olivier Messiaen. Other parts of the score were inspired by the Second Viennese School of Arnold Schoenberg and his pupils (Lund i2012).

The romantic comedy Almmiriika (Heaven; produced by Beaivváš Sámi Našunálateáhter in 2013) by Árni Ibsen was translated from the original Icelandic into North Sámi. It is about three women and three men who meet at a cabin for a weekend of drinking. These couples flirt, form love triangles and enjoy lusty flings while 
attempting (and failing) to cook, drinking a lot, and acting silly. The actors accompany non-Sámi popular songs with group choreography of stereotypical American line dance moves such as synchronous steps to the side, steps forward, clapping on the side of the body and putting hands on hips. Gunnarsson as director chose recordings mostly of popular songs and musicians attributed in Almmiriika's program as follows: "Love Shack," The B-52s; "Sparrow of the Wind," Vajas; "Gopher,"Yma Sumac; "I Want You Back," The Jackson 5; "Trololo," Eduard Khil; "This Land Is Your Land," Sharon Jones and The Dap Kings; and the new joik, "Goase dušše," by Nils-Aslak Valkeapää. Only Valkeapää’s joik recording features Sámi musicians.

Even if the theatre music is not of Sámi heritage originally, this does not mean that it does not engage or express Sáminess. Thus, on the one hand, such music may superficially be considered non-Sámi in the sense that it was composed and recorded by non-Sámi. On the other hand, it is for and "of" Sámi in that it was commissioned, selected, performed and/or played within a Sámi theatre production; at a culturally Sámi theatre company; and by a largely Sámi cast and crew. Globalized art and popular musics are a part of what it is to be Sámi and therefore engage Sáminess as well as express it. Sámi theatre frequently includes American, French, Austrian or other musical styles since theatre reflects life and, like most other peoples, Sámi engage diverse musical sounds from around the world in their everyday.

\section{Conclusion}

Sáminess expressed and engaged with music in Sámi theatre articulates Indigenous cosmopolitanisms. When its creative practices include everyday musical engagements, as with those artists accustomed to joiking or performing or composing other music genres, this can be called vernacular cosmopolitanism. When the musical expressions are rooted, for example, in specific ethnicities, nations, regions or spiritual beliefs, this can be viewed as rooted Indigenous cosmopolitanism.

Music in Sámi theatre also expresses different types of pan-Indigenous cosmopolitanism. This can be pan-Sámi (as in The Frost Haired and the Dream Seer), pan-Arctic Indigenous (as in Allaq) and pan-Indigenous in ways that engage culturally disparate Indigenous groups (such as with Sámi and African sounds in Gïeje). I described a variety of cosmopolitanisms, as well, that don't fit into any one of the said categories easily or at the same time. Adjectival cosmopolitanisms have their limits (Perman 2012) which is shown by the adjectives overlapping, being messy to separate and not being precisely applicable to real-life situations. 
Fundamentally, I showed that the Sáminess that emerges through music and musicking in Sámi theatre is fluid and changeable, interacting with diverse cultures and peoples while simultaneously carrying forward historical qualities of Sámi music and culture. Perhaps this Sáminess is so fluid in some cases that it is incongruent with using the theoretical frame of adjectival cosmopolitanism. Using adjectival cosmopolitanism means undertaking some essentialization. When one attributes an adjective to data interpreted as cosmopolitan (for example, the pan-Arctic of pan-Arctic Indigenous cosmopolitanism), one circumscribes a bounded label of cosmopolitanism.

The Sáminess I discussed is dynamic but also dynamically topical. Through complex cultural moves, the Sámi music theatre productions reproduce, create, and perform responses of Sámi and their artistic collaborators to contemporary social, political, and environmental contexts.

\section{Sources}

\section{Research Material}

\section{Discography}

Beaivváš (2010) Allaq. CD. Kautokeino: Beaivváš and DAT.

\section{Interviews}

Fjellheim, Frode (i2015) Trondheim, Norway 28 June 2008. Interview by author. Interview in possession of researcher.

Gaski, Harald (i2016) 29 Feb. 2016. Email communication with author.

Gunnarsson, Haukur J. (i2012) Kautokeino, Norway 25 Sept. 2012. Interview by author. Interview in possession of researcher.

Gunnarsson, Haukur J. (i2014) Kautokeino, Norway 3 Dec. 2014. Interview by author. Interview in possession of researcher.

Jürgensen, Ada Einmo (i2014) Mo i Rana, Norway 3 Sept. 2014. Interview by author. Interview in possession of researcher.

Kotilainen, Esa (i2013) Helsinki, Finland 6 Sept. 2013. Interview by author. Interview in possession of researcher.

Ludvigsen, Roger (i2013) Helsinki, Finland 6 Sept. 2013. Interview by author. Interview in possession of researcher.

Lund, Håvard (i2012) Kautokeino, Norway 25 Sept. 2012. Interview by author. Interview in possession of researcher. 
Mellem, Kristin (i2014) Tromsø, Norway 11 Sept. 2014. Interview with author. Interview in possession of researcher.

Persson, Cecelia (i2014) Mo i Rana, Norway 4 Sept. 2014. Interview by author. Interview in possession of researcher.

\section{Literature}

Appiah, Kwame Anthony (2006) Cosmopolitanism: Ethics in a World of Strangers. New York: W. W. Norton.

Chen, Xinjie. In progress. Rooted Cosmopolitanism of Sámi CDs in the 2000s. PhD dissertation manuscript, University of Helsinki.

DeLugan, Robin Maria (2010) "Same Cat, Different Stripes: Hemispheric Migrations, New Urban Indian Identities, and the Consolidation of a Cosmopolitan Cosmovision". Indigenous Cosmopolitans:Transnational and Transcultural Indigeneity in the Twenty-First Century. Ed. Maximillian C. Forte. New York: Peter Lang Publishing, Inc., 145-161.

DeNora, Tia (2021) On Arranging Cherries. https://careformusic.org/2021/08/06/ on-arranging-cherries/ (visited 12 August 2021).

Diamond, Beverley (2007) “'Allowing the Listener to Fly as They Want to': Sámi Perspectives on Indigenous CD Production in Northern Europe". The World of Music 40/1, 23-48.

Diamond, Beverley (2011) "Decentering Opera: Early Twenty First Century Indigenous Production". Opera Indigene: Re/presenting First Nations and Indigenous Cultures. Ed. Pamela Karantonis \& Dylan Robinson. Surrey, England and Burlington, VT: Ashgate, 31-56.

Forte, Maximillian C. (2010) "Introduction: Indigeneities and Cosmopolitanisms". Indigenous Cosmopolitans: Transnational and Transcultural Indigeneity in the Twenty-First Century. Ed. Maximillian C. Forte. New York: Peter Lang Publishing, Inc., 1-16.

Gunnarsson, Haukur (2012) Liner notes. Ritnoaivi ja nieguid oaidni [The Frost Haired and the Dream Seer]. CD. Kautokeino: Beaivváš and DAT.

Gaski, Harald (2008) "Yoik - Sami Music in a Global World". Indigenous Peoples: Self-determination, Knowledge, Indigeneity. Ed. Henry Minde. Utrecht: Eburon Academic Publishers, 347-360.

Gaski, Harald (2013) "Indigenism and Cosmopolitanism: A Pan-Sami View of the Indigenous Perspective in Sami Culture and Research". AlterNative: An International fournal of Indigenous Peoples 9/2, 113-124. https://doi.org/10.1177/117718011300900201

Harrison, Klisala (2019) "Sustainability and Indigenous Aesthetics: Musical Responses of Resilience in Sámi and Indigenous Canadian Theatre". Yearbook for Traditional Music 51, 17-48. https://doi.org/10.1017/ytm.2019.6 
Harrison, Klisala (2020) "Indigenous Music Sustainability during Climate Change". Current Opinion in Environmental Sustainability 43, 28-34. https://doi.org/10.1016/j.cosust.2020.01.003

Hilder, Thomas R. (2012) "Repatriation, Revival and Transmission: The Politics of a Sámi Musical Heritage". Ethnomusicology Forum 21/2, 161-179.

Hilder, Thomas R. (2014) Sámi Musical Performance and the Politics of Indigeneity in Northern Europe. Lanham, MD: Rowman \& Littlefield.

Jones-Bamman, Richard (1993) "As long as we continue to joik, we'll remember who we are": Negotiating Identity and the Performance of Culture: the Saami Joik. Ph.D. dissertation, University of Washington. https://doi.org/10.1080/07256860120069602

Jones-Bamman, Richard (2001) "From 'I'm a Lapp' to 'I am Saami': Popular Music and Changing Images of Indigenous Ethnicity in Scandinavia”. fournal of Intercultural Studies 22/2, 189-210.

Jouste, Marko (2009) "Traditional melodic types in the music of the Sámi in Finland". Perspectives on the Song of the Indigenous People of Northern Eurasia: Performance, Genres, Musical Syntax, Sound. Ed. Jarkko Niemi. Tampere: Tampere University Press, 240-266.

Jürgensen, Ada Einmo, and Klisala Harrison. 2016. "(De)colonizing Knowledge of Sámi Performing Arts: Music, Dance, Theatre.” Conference paper. Aktasne-Together: New Concepts, Theories and Methodologies on Saami Studies. Umeå University, Sweden, March 10-11.

Kvernmo, Marie (2014) Beaivváš - an Institution for Sámi Culture Management or Mainstream Entertainment? The Sámi National theatre's Role in the Sámi Community of Norway. Master's thesis, The Arctic University of Norway. Lehtola, Veli-Pekka (2013) "Staging Sami Identities: The Roles of Modern Sami Theatre in a Multicultural Context - The Case of Beaivváš Sámi Teáhter". L’Image du Sápmi. Ed. Kajsa Andersson. Örebro: Örebro University, 437-458.

Lehtola, Veli-Pekka \& Sigga-Marja Magga (2011) Beaivváš: Beaivváš Sámi Našunálateáhter, Berit Marit Hatta. Publications of the Sámi Museum Foundation no. 8. Inari: Sámi Museum Siida.

Levine, Victoria Lindsay \& Dylan Robinson (2019) Music and Modernity among First Peoples of North America. Middletown, CT: Wesleyan University Press.

Moisala, Pirkko (2011) "From Traditional Yoik (Joiku) Transmission towards Formal Education". Yoik: Aspects of Performing, Collecting, Interpreting. Ed. Dan Lundberg \& Gunnar Ternhag. Uppsala:The Center for Swedish Folk Music and Jazz Research, 43-64.

Perman, Tony (2012) "Sungura in Zimbabwe and the Limits of Cosmopolitanism". Ethnomusicology Forum 21/3, 374-401. https://doi.org/10.1080/17411912.2012.709815 
Proulx, Craig (2010) “Aboriginal Hip Hoppers: Representi’ Aboriginality in Cosmopolitan Worlds". Indigenous Cosmopolitans: Transnational and Transcultural Indigeneity in the Twenty-First Century. Ed. Maximillian C. Forte. New York: Peter Lang Publishing, Inc., 39-61.

Ramnarine, Tina K. (2009) “Acoustemology, Indigeneity, and Joik in Valkeapää's Symphonic Activism: Views from Europe's Arctic Fringes for Environmental Ethnomusicology". Ethnomusicology 53/2, 187-217.

Ramnarine, Tina K. (2015) "Frozen through Nordic frames". Puls: Swedish Fournal of Ethnomusicology and Ethnochoreology 1, 13-31.

Robinson, Dylan (2019) "Speaking to Water, Singing to Stone: Peter Morin, Rebecca Belmore, and the Ontologies of Indigenous Modernity". Music and Modernity among First Peoples of North America. Eds. Victoria Lindsay Levine \& Dylan Robinson. Middletown, CT: Wesleyan University Press, 220-239.

Sanakirja.fi (2021) Northern Sami - English. https://www.sanakirja.fi/sami-english (visited 26 October 2021).

Small, Christopher (1998) Musicking: The Meanings of Performing and Listening. Middletown, CT: Wesleyan University Press.

Webster-Kogen, Ilana (2014) "Song Style as Strategy: Nationalism, Cosmopolitanism and Citizenship in The Idan Raichel Project's Ethiopianinfluenced Songs." Ethnomusicology Forum 23/1, 27-48. https://doi.org/10.1080/17411912.2013.879034

Werbner, Pnina (2006) "Vernacular Cosmopolitanism." Theory, Culture E Society 23/2-3, 496-498. https://doi.org/10.1177/026327640602300291

Werbner, Pnina (2020) Anthropology and the New Cosmopolitanism: Rooted, Feminist and Vernacular Perspectives. 2nd ed. London: Routledge. https://doi.org/10.4324/9781003084617

UNPFII (United Nations Permanent Forum on Indigenous Issues) Factsheet (n.d.) Indigenous Peoples, Indigenous Voices. https://www.un.org/esa/socdev/ unpfii/documents/5session_factsheet1.pdf (visited 22 February 2021). 